\title{
LAND AND FINANCIAL RESOURCES FOR SOCIAL HOUSING: THE SOLIDARITY QUOTA IN SÃO PAULO'S 2014 MASTER PLAN ${ }^{1}$
}

\author{
TERRA E RECURSOS FINANCEIROS PARA A HABITAÇÃO SOCIAL: A COTA DE \\ SOLIDARIEDADE NO PLANO DIRETOR DE 2014 EM SÃO PAULO
}

\section{Debora Sotto ${ }^{2}$}

\begin{abstract}
This article's main objective is to analyse the solidarity quota's legal framework: an urban tool created by São Paulo's 2014 Master Plan in order to boost social housing projects through the levy of soil and financial resources. As quantitative data on its implementation is still unavailable due to the novelty of this tool, this study's starting point is the examination of the available official data on the ongoing social housing programmes and on the implementation of the Special Social Interest Zones - ZEIS. An extensive revision of the the applicable federal and local legislations is also conducted. The main elements and characteristics of the solidarity quota's legal framework are dully appointed and examined, with support on the review of relevant literature in the legal as well as in the urban planning fields. Lastly, the solidarity quota is compared with the Interconnected Operation, a precedent and similar urban tool valid in the city of São Paulo until the early 2000s, when it was ruled unconstitutional by the State Court of Law. The results obtained in this study indicate that the solidarity quota does represent an advance, as it intends to diminish spatial segregation, presenting a solution for soil and financial resources scarcity through value-capture.

Keywords: master plan; right to housing; segregation; social housing; zoning.
\end{abstract}

\section{Resumo}

O principal objetivo deste artigo é analisar o quadro jurídico da quota de solidariedade: uma ferramenta urbana criada pelo Plano Diretor de 2014, em São Paulo, a fim de impulsionar projetos de habitação social por meio arrecadação de solo e de recursos financeiros. Como os dados quantitativos sobre a sua implementação ainda não estam disponível devido à novidade desta ferramenta, ponto de partida deste estudo é a análise dos dados oficiais disponíveis sobre os programas de habitação social em curso e sobre a implementação das Zonas Especiais de Interesse Social - ZEIS. Também é realizada uma extensa revisão das legislações federais e locais aplicáveis. Os principais elementos e características do quadro jurídico da cota de solidariedade são devidamente apontados e examinadoscom apoio na revisão da literatura relevante não legal, bem como nas áreas de planejamento urbano. Por último, a cota de solidariedade é comparada com a Operação Interligada, um precedente e uma ferramenta urbana semelhante válida na cidade de São Paulo até o início dos anos 2000, quando foi considerada inconstitucional pela Corte do Estado de Direito. Os resultados obtidos neste estudo indicam que a cota de solidariedade representa um avanço, uma vez que tem a intenção de diminuir a segregação espacial, apresentando uma solução para a escassez do solo e dos recursos financeiros por meio do valor de captura.

Palavras-chave: plano diretor; direito à habitação; segregação; habitação social; zoneamento.

\footnotetext{
${ }^{1}$ This paper was presented at the $10^{\text {th }}$ International Conference on Planning, Law, and Property Rights - PLPR 2016, in Bern, Switzerland.

2 Procuradora do Município de São Paulo (2003). Doutora em Direito Urbanístico pela PUC/SP (2015). Pesquisadora do Grupo de Pesquisa Meio Ambiente Urbano - GPMAU da PUC/SP (2011). E-mail: dsotto@hotmail.com
} 


\section{INTRODUCTION}

São Paulo, the largest and richest city in Brazil, struggles against striking urban and social inequalities. There is a significant housing deficit, especially amongst the poorest families, with monthly incomes up to US\$6603. Even though many areas in the city have been reserved, as Special Social Interest Zones, to land regularization and to the construction of social housing, the budget available to implement these projects is insufficient to meet the city`s pressing needs.

In order to solve this problem, São Paulo's brand new Master Plan edited in 2014, has created an urban planning tool designated as a "solidarity quota". Through this mechanism, projects with an area superior to $20.000 \mathrm{~m}^{2}$ will be charged with a "quota" - the solidarity quota correspondent to ten percent of the project's area, which must be paid by the developer to the Municipality in the form of land, social housing units in the project itself, social housings units built elsewhere or in cash, deposited in the Municipality's Urban Development Fund.

The solidarity quotas significantly resemble another urban planning tool implemented by the city of São Paulo from the 1980's up to the early 2000's, designated as the "Interconnected Operations", by which the developers could acquire development rights in exchange of building social housing to slum dwellers in the city. The Interconnected Operations were indeed successful to implement social housing, but in areas located in the poor peripheries, thus aggravating the spatial segregation, which is a chronic problem in São Paulo. Following a judicial order, the Interconnected Operations had to be aborted in the early 2000's, as São Paulo's Court of Law ruled them unconstitutional for breaching the principle of the legal reserve.

When compared to the Interconnect Operations, the solidarity quotas do represent a significant development, as they intend to diminish - rather than aggravate - spatial segregation, operating in synergy with other urban tool, such as the Special Social Interest Zones - ZEIS and the Housing Programs. SINGER (1979 - p. 33) once stated that there is no place for the poor in the capitalist city. The solidarity quota is a hopeful attempt to open up space for the poor in a more just city. This is what we intend to demonstrate in our study.

\footnotetext{
${ }^{3}$ Considering an exchange rate of $\mathrm{R} \$ 4,00$ to US\$1,00.
} 


\section{SOCIAL HOUSING CHALLENGES IN SÃO PAULO: SCARCITY OF SOIL AND SHORTAGE OF FINANCIAL RESOURCES}

São Paulo is the largest and richest city in Brazil. It is located in the southeast portion of the country, and it spreads over an area of approximately 150 thousand hectares. According to the 2010 Brazilian Census ${ }^{4}$, the Metropolitan Region of São Paulo, which is integrated by the city of São Paulo and 38 other cities, is the 5th agglomeration in the planet, with a total of 19.683 .975 inhabitants. The city of São Paulo alone has a population of 11.253 .503 inhabitants. Its GDP at current prices has summed up to US\$140 billion dollars in the year of 2013; it is the highest GDP rate amongst Brazilian Municipalities.

According to the Brazilian Atlas of Human Development ${ }^{5}$, São Paulo has a Municipal Human Development Index - MHDI of 0,805 (very high), thus occupying the $28^{\text {th }}$ position in Brazil. From 1991 to 2010, São Paulo's MHDI has increased 17, 09\%, due to improvements in the education, longevity and income dimensions. Nevertheless, its Gini Coefficient, estimated at 0, 62, indicates significant inequality of income distribution in the city: $14,6 \%$ of the city's population is vulnerable to poverty ad $22,58 \%$ of the adults haven't completed basic education and are employed in informal jobs.

In an observation made in the 1990s, but yet fully actual and applicable to current times, SANTOS (2009 - p. 15) stated that, due to the apposition and overlapping of traces of economic opulence and signals of acute breakdown, São Paulo is an example of "incomplete modernity", for "all that is most modern can be found there, right next to the most gigantic needs".

The city's territorial organization - segregated and exclusionary - reflects its striking social inequalities and vulnerabilities. Richer districts concentrate in the centre and south-west portions of the city. Poor districts are distributed mostly in the periphery, predominantly at the east and far south portions of the city, and have the worst vulnerability indicators. Slums, informal settlements and tenements are abundant in the city: according to the Municipal Secretariat of Housing $\mathrm{SEHAB}^{6}$, there were 1643 slums, 357 urbanized settlements, 1087 tenements and 1042 informal settlements in São Paulo in the year of 2015.

As GROSTEIN (2001) points out, this urban sprawl pattern - oriented towards the periphery, with the increase in the number of slums and illegal subdivisions and significant

\footnotetext{
${ }^{4}$ Data compiled at: [http://infocidade.prefeitura.sp.gov.br].

${ }^{5}$ Digital platform, available at: [http://www.atlasbrasil.org.br].

${ }^{6}$ Data available at:[http:www.habisp.inf.br].
} 
environmental degradation - dramatically aggravates the living conditions of the poor, in São Paulo as well as in other Brazilian metropolises.

São Paulo also struggles against a significant housing deficit, which has been aggravated by the escalation in the residential units' prices, observed all over Brazil in the last few years. From January 2008 up to November 2015, in comparison to an inflation of approximately 60,4\%, house purchase prices in São Paulo have risen 224,8\% whereas rentals have augmented 91,9\%?

According to São Paulo's Municipal Housing Plan, in the year of 2009 approximately 890.000 dwellings demanded legal, urban or constructive regularization and 277.000 new dwellings were needed to eliminate the housing deficit in the city. Projections to 2014 estimated that at least 590.000 more dwellings would have to be constructed in order to provide for the increase in the housing deficit due to the demographic growth.

The 1988 Brazilian Constitution protects the right to housing alongside other social rights, such as health, education, labour and transportation. Accordingly, the implementation of housing programs, alongside with other essential urban services such as sanitation and transportation, is a common competence shared by all federate entities, here comprised the Union, the Federate States and the Municipalities.

Also, the Brazilian Statute of the City - a federal law which provides guidelines to the urban development policy to be observed by all federate entities - also ensures the right to housing to all city dwellers and city users as an inseparable component of the right to the sustainable city, which is expressly defined as "the right to urban soil, to housing, to sanitation, to infrastructure, to transportation and to public services, to work and to leisure, for the present and the future generations".

These legal provisions are perfectly coherent with the guidelines set by two international documents: the International Covenant on Economic, Social and Cultural Rights - ICESCR - a multilateral treaty set by the United Nations General Assembly in 1996 - and the World Charter for the Right to the City - set by social movements and non-governmental organizations assembled in the Social Forum for the Americas in Quito, 2004, the World Urban Forum in Barcelona, 2004, and the World Social Forum in Porto Alegre, 2005. In both documents, affordability and adequate living conditions - herein comprised an adequate location in the city - are presented as essential elements of the right to housing.

\footnotetext{
${ }^{7}$ According to the FIPE ZAP Index, available at: [http://www.zap.com.br/imóveis/fipe-zap-b/].
} 
Article 11, paragraph 1 of the ICESCR recognizes the right to housing as an essential component of the right to an adequate standard of living and of the right to the continuous improvement of living conditions. Accordingly, Article XIV, paragraph 1 of the World Charter for the Right to the City states that all cities, within the framework of their respective competences, should guarantee that housing fulfilling of adequate living conditions for all citizens and also affordable for all.

As SAULE JR. (2004 - p. 133) points out, the basic core of the right to housing is composed of three essential elements: security, peace and dignity. All these three elements strongly depend on the affordability and liveability provided by the dwellings, variables which, in the city, are in great dependence with another central element which is location.

Well located dwellings - provided with basic urban utilities and infrastructure and accessible to jobs and urban services - provide the best living conditions but are also less affordable, if not unaffordable at all, for the poor. Therefore, the fulfilment of the right to housing, as a pre-condition to the realization of the right to the city, strongly depends on the development of well structured housing public policies, to be implemented by governments in all three levels: national, regional and local.

In this context, in order to tackle São Paulo's social inequalities, the provision of affordable, well located dwellings for the poor must be one of the core objectives of the city's urban planning.

This has been recognised by São Paulo's 2014 Master Plan in various dispositions, of which two are worth mentioning in this study. First of all, the has elected the fulfilment of social rights, herein expressly included the right to housing, as targets to be pursued through the social function of property. Also, the Master Plan has appointed as one of its strategic objectives to reduce commuting in the city, through the balancing of the location of jobs and dwellings.

However, considering the city's many complexities and contradictions, two important obstacles must be overcome by city planners in order to make social housing viable and affordable to the poorest: the scarcity of soil and the shortage of financial resources.

\section{TACKLING THE SCARCITY OF SOIL: SPECIAL SOCIAL INTEREST ZONES - ZEIS}

São Paulo's two latest Master Plans, edited in 2002 and 2014, have made an attempt to overcome soil scarcity for social housing projects by marking out significant portions of the city's territory as Special Social Interest Zones - ZEIS, reserving these areas for land regularization and for the construction of social housing.

Revista de Direito da Cidade, vol. 08, no 3. ISSN 2317-7721 pp.842-858 846 
As PESSOA (2009, p. 55) points out, "the implementation of the ZEIS has originated from the necessity to recognize and incorporate the city produced by the low income population to the consolidated urban fabric". Therefore, the ZEIS main intent is to subtract portions of land from the real estate market, reserving them to the allocation of social housing and land regularization projects, to be conducted either by the public or private sectors, individually as well as in publicprivate partnerships.

The ZEIS is contemplated as an urban development tool both in the Statute of the City and in the Federal Law n. 11.977/2009, which has implemented Brazil's most recent National Housing Program, "Minha Casa Minha Vida" - PMCMV.

In juridical terms, the foundations for the delimitation of ZEIS in Brazilian cities lie within the principle of the social function of property, provided for in the Brazilian Constitution as a central element to the urban development policy. By this principle, the ownership of urban property implicates the duty to give his property an adequate destination, that is, a destination able to fulfil the guidelines set by the city's Master Plan.

Specific rules on land use, occupation and subdivision applicable to the ZEIS must be set by the city's Master Plan ${ }^{8}$. These specific ZEIS rules intend to guarantee the viability of social housing projects and land regularization initiatives. Non-residential uses are admitted in the ZEIS under predetermined conditions, established not only to assist the area's core destination, providing jobs and services to its residents, but also to integrate the ZEIS areas to the rest of the city, avoiding as well as remedying socio-spatial segregation.

There are, in general, two main types of ZEIS: the so-called "land regularization ZEIS", allocated on public or private areas already occupied by informal subdivisions and settlements inhabited by low income families, such as slums, tenements, irregular subdivisions and buildings; and the "urban voids ZEIS", allocated on large parcels of non-constructed urban soil or empty, derelict buildings in the city.

According to a study coordinated by SANTOS JR and MONTANDON (2011), amongst all the urban policy instruments introduced by the Statute of the City in 2001, the ZEIS is the urban tool most used by Master Plans in Brazil; nevertheless, the vast majority of these Master Plans have chosen to regulate only the land regularization type of ZEIS.

\footnotetext{
${ }^{8}$ It is important to note that, according to the Brazilian Constitution, Master Plans are mandatory for cities with a population superior to 20.000 inhabitants and must be approved in the form of a municipal law.
} 
In order to secure the achievement of the ZEIS goals and to avoid distortions, the Statute of the City determines that each ZEIS must be managed by a specific Management Council, to be integrated by representatives of all social actors implicated, such as residents, social housing movements, developers, associations, NGOs, the Municipal Administration, etc. Also, every ZEIS area must have a specific urbanization plan, to be elaborated, implemented and controlled through popular participation.

São Paulo's 2002 Master Plan - approved shortly after the Statute of the City's edition - has allocated 710 perimeters as ZEIS, correspondent to approximately $8,23 \%$ of the city's territory. The Zoning Law, edited in 2004, has increased these numbers to 964 perimeters allocated as ZEIS, correspondent to approximately 9,23\% of the Municipality's territory.

These perimeters were classified, according to their characteristics, in four types of ZEIS: ZEIS 1 - areas occupied by informal settlements, destined to land regularization projects; ZEIS 2 empty or underused grounds or plots; ZEIS 3 - well serviced areas with a predomination of empty or underused buildings and ZEIS 4 - empty plots or grounds, adequate for urbanization, located in environmental protection areas.

As SANTORO (2015) highlights, the Master Plan's original intent was to render the ZEIS attractive to developers by setting higher floor area ratios in comparison to other zones, mostly free of development rights payments; however, as the 2004 Zoning Law diminished the higher floor area ratios of other zones, the ZEIS ended up losing its attractiveness. As a result, according to ROLNIK and SANTORO (2014), in the period between 2003 and 2007, more social housing projects were built outside the ZEIS than inside the ZEIS, a scenario only reversed - according to the authors - with the launch of the Federal Housing Program "Minha Casa Minha Vida" in 2009.

São Paulo's 2014 Master Plan has made some adaptations to the ZEIS strategy, in the hopes of securing more soil for social housing in the city. It has created a fifth ZEIS category, ZEIS 5: an urban void ZEIS destined to the production of social housing for families of higher income rates, between US\$1320 and US\$2200. The number of perimeters augmented from 964 to 2281, in a total area of $41 \mathrm{~km}^{2}$, calculated to cope with the projected housing deficit for 2024 . However, the concrete results of these new provisions are yet to be observed. 


\section{TACKLING THE SHORTAGE OF FINANCIAL RESOURCES: FEDERAL AND MUNICIPAL SOCIAL HOUSING PROGRAMS}

As far as financial resources for social housing are concerned, an ambitious Program, called Minha Casa Minha Vida - PMCMV, has been launched by the Federal Government in 2009 to promote the production and the acquisition of dwellings by families with maximum incomes of US\$2200,009 , both in rural as in urban areas.

In urban areas, for families with maximum incomes of US\$1320,00, the Program operates through the granting of subsidies by the Federal Government, in order to complement the proponent's financial capacity to pay for the unit and, at the same time, protect the system's economical balance. For families with incomes between US\$1320,00 and US\$2200,00, the Program finances housing projects on special conditions, using resources from a federal fund.

Projects targeted on families with incomes up to US\$660,00 are organized by the State and/or by the Municipal Governments: they control the demand, indicating as potential buyers the families who have been previously included on a waiting list for social housing. Projects targeted for families with incomes from US\$660,00 to US\$2200,00, however, are freely launched and conducted by the private sector.

Even though it has been promoted as a housing program, the PMCMV core objective is to stimulate the country's economic growth through construction (KLINTOWITZ, 2011). From its launch in 2009 until November 2014, more than US\$90 billion have been invested - in subsidies as well as in credit - to finance the construction of 3,7 million dwellings all over the country, of which 1,87 million units have been already delivered (LOURENÇO; PEDRUZZI, 2016). In the same period, however, the housing deficit has raised most in the poorest social segment, of families with incomes up to US\$660 (LIMA NETO et al., 2013), who should have been the priority policy beneficiaries if PMCMV was truly a social housing program

PMCMV has also involuntarily replicated the segregated model of the high density Housing Complexes built in areas deprived of adequate services and infrastructure at the periphery of the great Brazilian cities in the 1980s and 1990s. RUFINO (2014) points out that, as PMCMV guidelines have set maximum value limits per project, increasing the maximum number of units per project from 500 units in 2009 to 5000 units in 2012, developers have exacerbated their profit margins by

\footnotetext{
${ }^{9}$ Considering an exchange rate of $\mathrm{R} \$ 4,00$ to US\$1,00.
} 
cutting costs on construction and land prices, building very large, standardized, projects in isolated peripheral areas, deprived of essential services and infrastructure.

Nevertheless, in a study comparing social housing production in São Paulo's ZEIS areas in the periods prior and subsequent to the PMCMV, ROLNIK and SANTORO (2014) have found a significant increase both in the number of units as in the occupation of grounds and plots located in the urban void ZEIS, as well as a better distribution of projects around the city, even though they have also found that the majority of the PMCMV projects did concentrate in the peripheral areas, including areas not allocated as ZEIS.

Parallel to this Federal Housing Program, the Municipality of São Paulo has structured its own Municipal Housing Policy, whose guidelines and institutions have been set by the Municipal Law n. 11.632/1994.

São Paulo's Municipal Housing System is integrated by a Municipal Housing Fund - FMH and three main administrative bodies: the Municipal Housing Secretariat - SEHAB : the central body, subordinate to the Mayor; the Metropolitan Housing Company of São Paulo - COHAB: the operational body, implemented as a joint capital company controlled by the Municipality; and a Municipal Housing Council - CMH: the system's consultant and deliberative body, composed by representatives from the Municipality and the civil society.

The Municipal Housing Fund is controlled and supervised by the Municipal Housing Council. It supports and finances the Municipal Housing Policy with resources from budget allocations, contributions, donations, loans, etc. Its main objectives are to diminish housing deficits and to upgrade housing conditions to the poorest through land regularization; slum upgrading; rental; home financing at lower rates; funding of housing units, urbanized lots and basic infrastructure; etc.

Other important source of financial resources for social housing in São Paulo is the Municipal Fund for Urban Development - FUNDURB, implemented by the City's 2002 and 2014 Master Plans in order to centralize benefit charges and payments made to the Municipality in exchange for the selling of development rights.

According to the Statute of the City, these resources must mandatorily finance social housing, land regularization, infrastructure, environmental and heritage preservation and the formation of a municipal land reserve. As the FUNDURB cannot pursue other objectives than those legally appointed, its resources are annually allocated and fully spent in the projects and programs pointed out by its Management Council, following the legislation's guidelines. This Management 
Council is integrated by representatives of the Administration and the civil society, and it is located at the Municipal Secretariat of Urban Development, which is in charge or urban affairs in general, especially urban planning and zoning.

Due to provisions set by the city's 2014 Master Plan, at least 30\% of the FUNDURB's annual resources must be spent with the acquisition of grounds and plots to the provision of social housing, preferably located in the urban voids ZEIS. Therefore, in 2013, US\$21,5 million were allocated to SEHAB Programs, of which approximately US\$20 million were dully spent. In 2014 US\$21,4 million were allocated, and US\$21 million were dully spent. In 2015, US\$18,85 million were allocated and, until June, US\$6,5 million have been already spent.

The scenario is entirely different in respect to the Municipal Housing Fund's expenditures. As most of its resources consist on budget allocations, which depend on the Municipality's tax collection performance, most of the allocated resources get "frozen" - in other words, are made unavailable for expenditure - as social housing and land regularization projects often cannot "compete" with other Municipal priority spending, such as salaries, transportation, health and educational services.

The numbers speak for themselves: in 2013, from US\$33,15 million allocated, US\$19,9 million were frozen and only US\$13,25 spent; In 2014, from US\$23,4 million allocated; US\$17million were frozen, and only US\$2,95 million were spent until August 2014.

In terms of on-going social housing projects, in October 2015, the SEHAB was engaged in the production of 190.767 dwellings: 124.205 dwellings (284 projects) were in the design phase; 18.968 units (35 projects) had just started construction; 19.148 (94 projects) were in construction; 8.586 (61 projects) started in 2013 were already concluded; 19.664 units (30 projects) were in studies phase and 196 units ( 1 project) were awaiting the expropriation of areas ${ }^{10}$.

As impressive as these numbers are, they are far from being sufficient to meet the city's pressing needs. The coordinate handling of ZEIS with Federal and Municipal Funds and Housing Programs - even with resources pre-destined to housing, tried out in São Paulo since the edition of the city's 2002 Master Plan, has not been able to successfully overcome the two main obstacles to the effective provision of social housing in the city: scarcity of soil and insufficiency of financial resources.

\footnotetext{
${ }^{10}$ Data available at: [http://www.habisp.inf.br].
} 


\section{THE SOLIDARITY QUOTA: TACKLING THE SCARCITY OF LAND AND FINANCIAL RESOURCES}

In order to tackle the scarcity of soil and financial resources, São Paulo's latest Master Plan, edited in 2014, has introduced a new urban planning tool, designated as "solidarity quota".

The solidarity quota is very similar to the United States' inclusionary zoning, by which the federate States can grant local governments the powers to compel or to stimulate developers to include affordable housing in new residential developments (COWAN, 2006).

According to São Paulo's 2014 Master Plan, projects with an area superior to $20.000 \mathrm{~m}^{2}$ must be charged with a "quota" - the solidarity quota - equivalent to $10 \%$ of the project's plot area, which must be paid by the developer to the Municipality in the form of social housing units inserted in the project itself. In return to the payment of the solidarity quota - which operates as a value-capture tool - the project can benefit of an increase of ten percent in the usable floor area, to be obtained through the purchase of the correspondent development rights. The Master Plan's intent in this case is to stimulate the construction of mixed-use developments, as well as to promote greater housing variety and density within the same project.

As a value-capture tool - designed to capture a portion of the development's added value and reverse it in favour of the community, in this case, in the form of social housing units - the solidarity quota finds its legal basis not only in the principle of the social function of property but also in the equitable distribution of charges and benefits.

According to LIBORIO (2004 - p. 53), the equitable distribution of charges and benefits - a legal principle set by the Statute of the City - "translates the isonomic treatment that must be given to every person affected by the urbanization process". In what refers to the solidarity quotas, this equitable distribution of charges and benefits implicates that larger developments, which generate significant impact in the urban environment, are demanded to compensate these impacts with the construction of social housing.

Besides building the social housing units within the development, the developer can choose one amongst three other possible options. The first one is to build another social housing development, with at least the same area demanded by the solidarity quota (that is, $10 \%$ of the original project's plot area), in any other ground or plot located in the Municipality's Macro Zone of 
Urban Structuring and Qualification ${ }^{11}$. The second possible option is to donate to the Municipality another ground or plot, of equivalent value, also located in this Macro Zone. The third and last possible option is to deposit the solidarity quota's value in the FUNDURB; in this case, this payment can only be used to purchase soil for social housing or to grant subsidies to social housing projects, preferably in the urban voids ZEIS. In both the second and third options, the evaluation must be done accordingly to the Land Value Register used to calculate development rights prices. In all of these three alternatives, the solidarity quota operates as a plus value-capture instrument - paid either in soil or in financial resources - but it does not stimulate mixed uses or housing variety within the same development.

In our opinion, the ideal situation would be to obligate the developer to build social housing units in the same development or, at least, provide for social housing units or soil located in the proximities of the original development, at least, in the same Macro Area.

The Master Plan's original legislative proposal, as submitted to the City Hall by the Administration, determined that the developers should pay the solidarity quota in social housing units or soil located in the same Macro Area as the intended development. The proposal, however, was modified by the City Council, authorizing developers to offer social housing units or soil located anywhere in the Macro Zone of Urban Structuring and Qualification, with exception of the Vulnerability Reduction Macro Area and some Sectors of the Metropolitan Structuring Macro Area reserved by the Master Plan to special urban rehabilitation projects.

According to WHITAKER (2014) and COSTA et al (2015), the final version of the Master Plan has compromised the tool's efficacy, enabling developers to pay the solidarity quota with poorly located soil, instead of obliging them to provide social housing or soil in areas as well located as their own developments.

COSTA et al (2015) point out additionally that the solidarity quota rates could be much higher than $10 \%$, pointing out experiences on inclusionary zoning where developers are obliged to render the equivalent of up to $25 \%$ of the development's area in social housing units.

\footnotetext{
${ }^{11}$ São Paulo's territory has been divided by its 2014 Master Plan into two main Macro Zones: The Macro Zone of Urban Structuring and Qualification, in the central portions of the city, and the Macro Zone of Environmental Protection and Rehabilitation, in the city's periphery, coincidental with water sources and environmental protection areas. The Macro Zone of Urban Structuring and Qualification is divided in four different Macro Areas, according to its characteristics and functions: Metropolitan Structuring Macro Area; Consolidated Urbanization Macro Area; Urban Qualification Macro Area and Vulnerability Reduction Macro Area.
} 
WHITAKER (2014) also criticizes the possibility to pay the solidarity quota in cash, affirming that the Municipality has yielded to the interests of the real developers, giving up the chance to compel the market to assign well located soil - most of it retained in speculation - to social housing.

Although such criticisms are undoubtedly relevant, we consider that the solidarity quota does represent a positive step towards rendering the city less segregated and unjust, as it can help reduce spatial segregation, operating in synergy with the Municipal Housing Program and the Special Social Interest Zones.

If the solidarity quota is paid in financial resources, these can fund the construction of social housing in the well-located and well-serviced urban void ZEIS. On the other hand, if the solidarity quota is paid with soil, these plots and grounds can receive social housing projects, built accordingly to the Municipal Housing Program guidelines. Both alternatives can contribute to reduce the housing deficit in a non-segregated way through the construction of good quality, well located social housing units.

\section{THE INTERCONNECTED OPERATIONS: PREDECESSORS TO THE SOLIDARITY QUOTA?}

The solidarity quota significantly resembles another urban planning tool implemented in the city of São Paulo between the 1980's and the early 2000's - prior to the edition of the federal Statute of the City - designated as "Interconnected Operations", by which developers would acquire development rights in exchange of social housing to slum dwellers in the city.

The Interconnected Operations were implemented by two successive municipal laws: 10.209/1986 and 11.773/1995. The Municipal Law 10.209/1986 allowed the owners of grounds or plots which had been occupied by slums or illegal subdivisions to present a petition to the Administration, asking for the concession of development rights in return for the construction and donation of social housing units for the slum or illegal subdivision's inhabitants.

This petition had to be instructed with an operational plan, indicating the grounds where the social housing units were to be built, as well as a detailed description of the development rights to be awarded and the location where these development rights would be applied. The petition would be examined by a Zoning Commission and, if the proposal was approved, the Municipal Secretariat of Planning would issue a certificate, stating the development rights granted to the developer.

The Municipality was also allowed to issue public bids, summoning developers to submit proposals to provide social housing units for the inhabitants of slums or illegal subdivisions on 
municipal grounds, in exchange for the granting of development rights to be freely applied in grounds or plots of the developer's choice.

Whether the Interconnected Operation involved informal settlements built on private or on public grounds, the Municipality had no control whatsoever neither on the placement of the social housing units nor on the location of the grounds or plots where the development rights would be finally applied.

According to SANDRONI (2004), one of the biggest transactions held in São Paulo was the Interconnected Operation 1 West Plaza: the developer built 810 social housing developments, worth approximately US\$9,6million dollars, in exchange for development rights applied to the construction of a Shopping Mall at the beginning of the 1990s.

The Interconnected Operations procedures were altered in 1995 by the Municipal Law n.11.773. The Administration would issue public bids to summon the developers, appointing the social housing projects intended to be built. The developers would submit their proposals to a Planning Legislation Committee that would approve the granting of development rights and determine its price, never inferior to $60 \%$ of the surplus value to be obtained by the developer. Therefore, instead of building the social housing units themselves, developers had to make payments to the Municipal Housing Fund, in exchange to the granting of development rights. A commitment term would be signed and a certificate of development rights would be issued to the developer.

As in the procedures regulated by the Municipal Law n. 10.209/1986, the Administration still had no control over the location of the grounds where the development rights would be applied, with exception of some prohibitions placed by law, such as environmental protection areas and low density residential zones.

In the early 2000's, following a judicial order, the Interconnected Operations had to be aborted, as São Paulo's State Court of Law ruled them unconstitutional for breaching the principle of legal reserve, for they allowed the City's Administration to alter development rights contrary to the city's Master Plan and Zoning Laws dispositions. However, all Interconnected Operations approved by the Administration prior to the judicial order were maintained by the Court.

The similarities between the Interconnected Operation and the solidarity quota lie essentially in the fact that both urban tools were built upon the exchange of development rights for social housing units. Nevertheless, when compared to the Interconnected Operation's legal framework, the solidarity quota is not only technically superior but also more equitable. 
First of all, in the solidarity quota's legal framework, the grant of development rights is entirely ruled by the municipal law, so there is no breaching of the Master Plan's provisions on density and land occupation; also, the Municipality has kept some degree of control over the location of the social housing units, whether they are to be built by the developers or by the Administration itself.

Additionally, even though the Interconnected Operations were indeed successful to implement social housing, they have aggravated rather than alleviated spatial segregation in the city, as they have fostered the displacement of the poor to the far peripheries, where the social housing units were built.

The solidarity quota, on the contrary, is clearly targeted to diminish - rather than aggravate - spatial segregation, presenting a rather ingenious solution for soil and financial resources scarcity to affordable, well-located social housing through value-capture, specially if operated in synergy with the ZEIS and the Municipal Housing Program.

\section{CONCLUSIONS}

Despite its limitations, the solidarity quota does represent a significant development for the city's housing policy, specially when compared to its historical predecessors, the 1980's and 1990's Interconnected Operations, as it is targeted to diminish - rather than aggravate - spatial segregation, attributing to the Municipality the power to decide on the location of the social housing units and thus operating in synergy with the ZEIS and the Municipal Housing Program.

Due to the novelty of this tool, there is still no quantitative data on its implementation available for evaluation. However, we believe that the critical analysis of the solidarity quota's legal framework can contribute to the development, as well as the refinement, of other urban planning tools in cities which, as São Paulo, need to tackle the scarcity of land and financial resources in order to fully implement the right to housing for the poor.

\section{REFERENCES}

COSTA, A.; ALBUQUERQUE, G.; RAMPAZIO, L. Cota de solidariedade: comparando políticas entre cidades Norte Americanas e São Paulo. PARC Pesquisa em Arquitetura e Construção, Campinas, SP, v. 6, n. 1. ISSN 1980-6809, 56-68. Accessed on 05.10. 2015. Available at: [http://periodicos.bc.unicamp.br/ojs/index.php/parc/article/view/8635024]. 
COWAN, S. Anti-snob land use laws, suburban exclusion, and housing opportunity. Journal of Urban Affairs, vol. 28 (3) - June, 2006.

GROSTEIN, M. Metrópole e Expansão Urbana: a persistência de processos "insustentáveis". São Paulo Perspec. 2001, vol.15, n.1. p. 13 a 19.

KLINTOWITZ, Danielle C. Como as políticas habitacionais se inserem nos contextos da reforma do Estado? A experiência recente no Brasil. Revista Pensamento \& Realidade. Ano XIV, v. 26, n.3, 2001. p. 101 a 120.

LIBÓRIO, D. Elementos de Direito Urbanístico. Barueri: Malheiros, 2004.

LIMA NETO, Vicente Correia; FURTADO, Bernardo Alves; KRAUSE, Cleandro. Nota Técnica no. 5: Estimativas do Déficit Habitacional Brasileiro PNAD 2007-2012. Brasília: IPEA, novembro de 2013.

LOURENÇO, Luana; PEDRUZZI, Pedro. Minha Casa Minha Vida deve cumprir meta de 3.75 milhões de moradias em 2014. Agência Brasil, 11 de dezembro de 2014. Available at: [http://agenciabrasil.ebc.com.br/geral/noticia/2014-12/minha-casa-minha-vida-deve-cumprirmeta-de-375-milhoes-de-moradias-em-2014]. Accessed on 09.01. 2016.

PESSOA, D. Estudo da produção de HIS (Habitação de Interesse Social) e HMP (Habitação de Mercado Popular) nas ZEIS (Zonas Especiais de interesse social) da Subprefeitura da Lapa, Município de São Paulo a partir do PDE (Plano Diretor Estratégico) de 2002. Pós, v.16. São Paulo, dezembro 2009. p. $50-60$.

PNUD; FUNDAÇÃO JOÃO PINHEIRO; IPEA. Atlas do Desenvolvimento Humano no Brasil. 2016. Available at: [http://www.atlasbrasil.org.br].

RUFINO, Maria Beatriz Cruz. The Minha Casa Minha Vida Program (PMCMV) and the increasing influence of markets in the production of social housing: discussion of the recent changes on the Brazilian context and the European debate on the theme. Paper. Utrecht: AESOP, 2014.

SANDRONI, P. La operación interligada West-Plaza: un caso de apropriación de renta en la ciudad de São Paulo. Curso de Financiamiento de las Ciudades Latinoamericanas con Suelo Urbano. Cambridge-MA: Lincoln Institute of Land Policy, 2004.

SANTOS, M. Metrópole Corporativa Fragmentada - O Caso de São Paulo. 2a. edição. São Paulo: Edusp, 2009.

SANTOS JR, O.; MONTANDON, D. (org.). Os planos diretores municipais pós-estatuto da cidade: balanço crítico e perspectivas. Rio de Janeiro: Ministério das Cidades; Letra Capital; Observatório das Cidades; IPPUR/UFRJ. 2011.

SAULE JR, N. A proteção jurídica da moradia nos assentamentos irregulares. Porto Alegre: Sergio Antonio Fabris Editor, 2004.

SINGER, P. O uso do solo urbano na economia capitalista. in MARICATO, Ermínia. A Produção Capitalista da Casa (e da Cidade). São Paulo: Alfa Ômega, 1979. p. 21 a 36. 
SECRETARIA MUNICIPAL DE HABITAÇÃO. Plano Municipal de Habitação - A experiência de São Paulo. $1^{\text {a }}$ edição. São Paulo: Prefeitura do Município de São Paulo, 2012. Available at: [http://www.habisp.inf.br/theke/documentos/pmh/2012/pmh_vol1_port/index.html]. Accessed on 20.05.2016.

ROLNIK, R.; SANTORO, P.. Zonas Especiales de Interés Social (ZEIS) e ciudades brasilinas: Trayectoria reciente de implementación de un instrumento de política de suelo. In: FURTADO, Fernanda; SMOLKA, Martim O. (2014). Instrumentos Notables de Políticas de Suelo en América Latina. Ecuador: Ministério das Cidades; Lincoln Institute of Land Policy; Banco del Estado Ecuador, 2014.

SANTORO, P. O redesenho dos instrumentos urbanísticos e a equação (im)possível da garantia de rentabilidade da terra e do direito à cidade nos projetos urbanos. in: ANPUR. Anais do XVI ENANPUR. Espaço, planejamento e insurgências. Belo Horizonte, 2015. Available at: [http://xvienanpur.com.br/Anais/?wpfb_dl=310]. Accessed on 20.05.2016.

SECRETARIA MUNICIPAL DE DESENVOLVIMENTO URBANO. Infocidade. São Paulo: Prefeitura do Município de São Paulo, 2016. Available at: [http://infocidade.prefeitura.sp.gov.br].

SECRETARIA MUNICIPAL DE HABITAÇÃO. Habisp. São Paulo: Prefeitura do Município de São Paulo, 2016. Available at: [http://www.habisp.inf.br].

WHITAKER, J. O patrimonialismo e as leis facultativas: o caso da cota de solidariedade em são Paulo. Cidade para que $(\mathrm{m})$ ?. São Paulo, 29 nov. 2014. Available at: [http://cidadesparaquem.org/blog/2014/11/29/o-patrimonialismo-e-as-leis-facultativas-o-caso-dacota-de-solidariedade-em-sao-paulo]. Accessed on 15.01.2016.

ZAP IMÓVEIS. Índice FIPE-ZAP. Rio de Janeiro: Grupo Globo, 2016. Available at: [http://www.zap.com.br/imoveis/fipe-zap-b/].

Trabalho enviado em 21 de maio de 2016.

Aceito em 09 de junho de 2016. 